\title{
Introduction to the Feature Issue on Slow Light and Its Applications
}

\author{
Boyd, Robert W.; Hau, Lene; Wang, Hailin; Eisenstein, Gadi; Noda, Susumu; Mørk, Jesper
}

Published in:

Journal of Lightwave Technology

Link to article, DOI:

10.1109/JLT.2008.2010572

Publication date:

2008

Document Version

Publisher's PDF, also known as Version of record

Link back to DTU Orbit

Citation (APA):

Boyd, R. W., Hau, L., Wang, H., Eisenstein, G., Noda, S., \& Mørk, J. (2008). Introduction to the Feature Issue on Slow Light and Its Applications. Journal of Lightwave Technology, 26(23), 3707-3707.

https://doi.org/10.1109/JLT.2008.2010572

\section{General rights}

Copyright and moral rights for the publications made accessible in the public portal are retained by the authors and/or other copyright owners and it is a condition of accessing publications that users recognise and abide by the legal requirements associated with these rights.

- Users may download and print one copy of any publication from the public portal for the purpose of private study or research.

- You may not further distribute the material or use it for any profit-making activity or commercial gain

- You may freely distribute the URL identifying the publication in the public portal 


\section{Introduction to the Feature Issue on Slow Light and Its Applications}

W E are pleased to present this feature issue coordinated between the Journal of the Optical Society of America B (JOSA B) and the JOURNAL OF LIGHTWAVE TECHNOLOGY (JLT) on fundamental and applied aspects of slow light. The joint issue between the two journals reflects the tremendous breadth of this field; it is the strong feeling of the editors that research in slow light spans both fundamental and applied issues, and for this reason a joint venture between the two journals was in order.

We have been accustomed to thinking of the speed of light as being a fundamental constant, as it is for propagation through vacuum, or of having a value close to the vacuum speed, as when light propagates through ordinary optical materials. Yet it has recently become clear that tools exist that allow one to slow down, speed up, or even completely stop light propagation. This realization has had a profound impact on the optics community, both from the point of view of fundamental science and in that it has led to the exploration of a number of practical applications within modern optical technology.

Early work in slow and fast light was aimed largely at developing physical mechanisms that could lead to a control over the propagation velocity of light pulses and at examining any fundamental limitations to the ability to modify the total delay or advancement of optical waveforms. This work led to the development of many physical processes that could lead to slow and fast light, including electromagnetically induced transparency, coherent population oscillations, four-wave mixing and parametric processes, absorption or gain saturation, stimulated Brillouin and Raman scattering, and passive and active manipulation in periodic structures and resonators. The goal of being able to exercise control over the velocity of light also led to the development of new optical materials and structures with properties fine tuned to these applications. Some of the materials and structures include photonic crystals and other periodic structures, metamaterials, including plasmonic structures, new optical fibers, including holey fibers, semiconductor nanostructures, including quantum wells and quantum dots, saturable optical amplifiers and absorbers, Bose-Einstein condensates and hot vapor atomic cells, and other solid-state materials.

Digital Object Identifier 10.1109/JLT.2008.2010572
Perhaps most importantly, as the physical understanding of slow light processes matured, the field moved in the direction of developing more and more sophisticated applications of slow light. Some of these applications include all-optical buffers and routers for optical communications, microwave photonics, microwave filters and phased-array systems, sampling systems, and sensors and improved measurement systems.

The goal of this Feature Issue is to define the current state-ofthe-art in Slow Light. To this end, we are publishing 31 articles that present overviews and cutting-edge research reports on slow light fundamentals and technology. The Table of Contents for the complete coordinated Feature Issue is being published in both journals. The feature issue of JOSA B contains papers related to the fundamental physical processes related to generation of slow light. The companion issue in JLT focuses on papers dealing with devices, applications, and engineering-related aspects of slow light.

\author{
ROBERT W. BOYD, Coordinating Guest Editor \\ University of Rochester \\ Rochester, NY 14627-0171 USA \\ LENE HAU, Guest Editor, JOSA B \\ Harvard University \\ Cambridge, MA 02138 USA
}

HAILIN WANG, Guest Editor, JOSA B

University of Oregon

Eugene, OR 97403 USA

GADI EISENSTeIn, Guest Editor, JLT

Technion-Israel Institute of Technology

Haifa, Israel

Susumu NodA, Guest Editor, JLT

Kyoto University

Kyoto, Japan

JESPER MOERK, Guest Editor, JLT

Technical University of Denmark

Lyngby, Denmark 